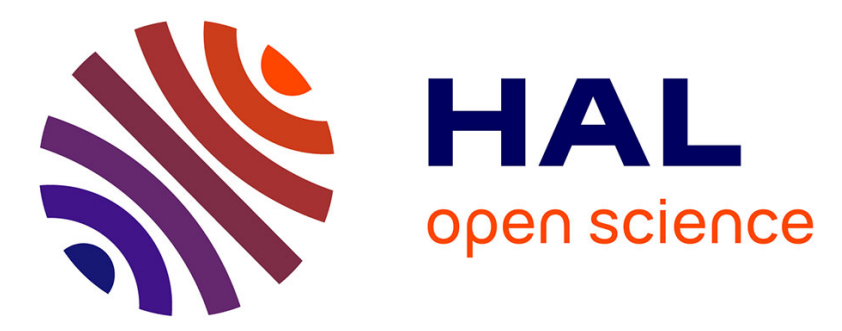

\title{
Developing Remote Metal Binding Sites in Heteropolymolybdates
}

Pierre R. Marcoux, Bernold Hasenknopf, Jacqueline Vaissermann, Pierre

Gouzerh

\section{- To cite this version:}

Pierre R. Marcoux, Bernold Hasenknopf, Jacqueline Vaissermann, Pierre Gouzerh. Developing Remote Metal Binding Sites in Heteropolymolybdates. European Journal of Inorganic Chemistry, 2003, 2003 (13), pp.2406-2412. 10.1002/ejic.200200677 . cea-02528430

\section{HAL Id: cea-02528430 https://hal-cea.archives-ouvertes.fr/cea-02528430}

Submitted on 1 Apr 2020

HAL is a multi-disciplinary open access archive for the deposit and dissemination of scientific research documents, whether they are published or not. The documents may come from teaching and research institutions in France or abroad, or from public or private research centers.
L'archive ouverte pluridisciplinaire HAL, est destinée au dépôt et à la diffusion de documents scientifiques de niveau recherche, publiés ou non, émanant des établissements d'enseignement et de recherche français ou étrangers, des laboratoires publics ou privés. 


\section{Anderson-Type Heteropolymolybdates Containing Tris(alkoxo) Ligands, 2. ${ }^{\text {\$l }}$ Elaboration of Remote Metal Binding Sites}

5 Bernold Hasenknopf, ${ }^{[a]}$ Pierre Marcoux, ${ }^{[a]}$ Jacqueline Vaissermann, ${ }^{[a]}$ and Pierre Gouzerh*[a]

Polyoxometalates / Molybdenum / N ligands $\{$ Insert up to 5 keywords. $\} /\{\ldots\} /\{\ldots\}$

$\overline{\text { Anderson-type polyoxomolybdates }\left[\mathrm{MMo}_{6} \mathrm{O}_{18}\left\{\left(\mathrm{OCH}_{2}\right)_{3} \mathrm{CNH}_{2}\right\}_{2}\right]^{3-}\left(\mathrm{M}=\mathrm{Mn}^{\mathrm{III}}, \mathrm{Fe}{ }^{\mathrm{III}}\right) \text { were prepared }}$ and structurally characterized. The trisalkoxo ligands are bound to the central heteroatom by their oxygen atoms. The corresponding compounds with $\mathrm{M}=\mathrm{Ni}^{\mathrm{II}}$ or $\mathrm{Zn}^{\mathrm{II}}$ are unavailable because of the preference of these cations for the amine function. The pendant amine groups of the manganesecontaining derivative were reacted with pyridine-carbaldehydes to give the corresponding imines which provide new mono- and bidentate binding sites for metal cations.

${ }^{[\$]}$ Part 1: See ref. $[\{$ Insert reference number $\}]$. $\{\{$ or: $\}\}$ See $\{$ insert citation $\}$.

20 [a] Laboratoire de Chimie Inorganique et Matériaux Moléculaires, UMR 7071,

Université Pierre et Marie Curie, Case Courrier 42, 4 place Jussieu, 75252 Paris cedex 05, France

Fax: (+33) 144273841

E-mail:pg@ccr.jussieu.fr 


\section{Introduction}

Organic molecules can be grafted onto polyoxometalates (POMs). ${ }^{[1]}$ This provides an entry in the field of organic/inorganic hybrid compounds which combine the properties of the metal-oxo cluster and the organic component. ${ }^{[2 ; 3]}$ Such functionalized POMs have been used in the preparation of

5 polymers, ${ }^{[4-7]}$ dendrimers ${ }^{[8]}$ or macroporous materials ${ }^{[9]}$ by covalently crosslinking the organic groups. The complexation of other metal ions at a remote site of the grafted organic ligand is less common. Maatta et al. prepared a hexamolybdate with a pendant ferrocene group. ${ }^{[10]}$ In this case, the preformed organometallic complex was attached to the polyoxomolybdate. To the best of our knowledge, no complex formation with a ligand already bound to a polyoxometalate is reported in the litterature. On the other hand, there are many examples in the literature where POMs bind other metal ions through their oxo ligands. ${ }^{[11]}$ In particular, lacunary POMs can be combined with a variety of metal cations, and the resulting complexes have interesting new electrical, optical, magnetic or catalytic properties. ${ }^{[12-18]}$ Also giant POMs can be generated in this way. ${ }^{[19]}$

Thus, our interest focused in the combination of POMs and other metals via organic ligands. This strategy is complementary to the coordination of oxo ligands in order to "bridge the gap between polyoxometalates and classic coordination compounds". ${ }^{[20]}$ The organic molecules might display other donor atoms than oxygen and may vary their arrangement in the binding site. Therefore, the ligand can be adjusted to the chemical and geometrical preferences of the extra metal centres. Ideally, our approach would permit to select a specific ligand for a chosen metal ion, and to connect it to a chosen POM. The properties of the resulting assembly would be tuned by the individual optimization of the components.

The realization of this concept requires the development of a flexible synthetic strategy. A key role comes to the organic linker between the POM and the remote coordination site. This molecule has to be bifunctional with one side that can merge with a POM, and a reactive group on the other side

25 to build the coordination site. We chose tris(hydroxymethyl)aminomethane $\left(\left(\mathrm{HOCH}_{2}\right)_{3} \mathrm{CNH}_{2}\right.$, TRIS) for this purpose. The triol moiety can be incorporated in Anderson, ${ }^{[21]}$ Lindqvist, ${ }^{[22-24]}$ 
Dawson $^{[8 ; 25]}$ or other POMs. ${ }^{[25-27]}$ The remaining amino group can be used to elaborate the coordination site. We chose first to look at the incorporation of TRIS into Anderson-type polyoxomolybdates.

The Anderson structure $\left[\mathrm{H}_{x}\left(\mathrm{M}^{\prime} \mathrm{O}_{6}\right) \mathrm{M}_{6} \mathrm{O}_{18}\right]^{\mathrm{n}-}(x=0-6, n=2-6)$ consists of a planar arrangement of

5 six edge-sharing $\mathrm{MO}_{6}(\mathrm{M}=\mathrm{Mo}, \mathrm{W})$ octahedra around a central heteroatom $\mathrm{M}^{\mathrm{r}}{ }^{[28-30]}$ We have shown recently that two tris(hydroxymethyl)methane residues $\mathrm{RC}\left(\mathrm{CH}_{2} \mathrm{O}\right)_{3}\left(\mathrm{R}=\mathrm{CH}_{3}, \mathrm{CH}_{2} \mathrm{OH}\right.$, $\mathrm{CH}_{2} \mathrm{NO}_{2}$ ) can cap both sides of the polyanion. ${ }^{[21]}$ Two forms were found: in the first one -named $\delta$ for its approximate $D_{3}$ symmetry- the triol is bound entirely to the heteroatom, while in the second one -named $\chi$ for its approximate $C_{2 v}$ symmetry- it is capping a tetrahedral cavity. The central heteroatom can be a di- or trivalent transition metal cation, and we have prepared compounds with $\mathrm{Mn}^{\mathrm{III}}, \mathrm{Fe}^{\mathrm{III}}, \mathrm{Ni}^{\mathrm{II}}$ and $\mathrm{Zn}^{\mathrm{II}}$ and the above mentioned tris(hydroxymethyl)methane derivatives. We present here the results of the reactions with TRIS and the derivatization of the pendant amine group. The protonated form of TRIS has been used as counterion for polyoxometalates. ${ }^{[31]}$ Also, amide and tertiary amine derivatives have been incorporated into POM frameworks, ${ }^{[23 ; 32]}$ but to the best of our knowledge, TRIS itself has not been incorporated into POMs yet. Difficulties with this compound have been linked to its role as a reductant. ${ }^{[32]}$

\section{Results and Discussion}

\section{Grafting a free amine group on a POM}

20 Treatment of $\left[\mathrm{N}\left(\mathrm{C}_{4} \mathrm{H}_{9}\right)_{4}\right]_{4}\left[\alpha-\mathrm{Mo}_{8} \mathrm{O}_{26}\right]$ with TRIS in the presence of manganese(III) acetate gave $\left[\mathrm{N}\left(\mathrm{C}_{4} \mathrm{H}_{9}\right)_{4}\right]_{3}\left[\mathrm{MnMo}_{6} \mathrm{O}_{18}\left\{\left(\mathrm{OCH}_{2}\right)_{3} \mathrm{CNH}_{2}\right\}_{2}\right] \mathbf{1}$ which was isolated as orange cristals in $80 \%$ yield. The compound was characterized by single crystal X-ray diffraction. Crystal structure data are summarized in Table 1. The overall molecular structure of the anion (Figure 1) is very similar to the analogous compounds reported. ${ }^{[21]}$ Six edge-sharing $\mathrm{MoO}_{6}$ octahedra are arranged around a central

$25 \mathrm{MnO}_{6}$ unit forming the Anderson structure. The two organic moieties cap both sides of the planar 
hexagon. The alkoxo ligands are all bound to the $\mathrm{Mn}^{\mathrm{III}}$ ion, thus the structure corresponds to the $\delta$ type. Selected bond lengths and angles are compiled in Table 2. The rigidity of the POM framework prevents the $\mathrm{Mn}^{\mathrm{III}}$ ion to undergo marked Jahn-Teller distortions. The coordination octahedron is only very slightly elongated.

5 The reaction of $\left[\mathrm{N}\left(\mathrm{C}_{4} \mathrm{H}_{9}\right)_{4}\right]_{4}\left[\alpha-\mathrm{Mo}_{8} \mathrm{O}_{26}\right]$ with TRIS in the presence of iron(III) acetylacetonate gave $\left[\mathrm{N}\left(\mathrm{C}_{4} \mathrm{H}_{9}\right)_{4}\right]_{3}\left[\mathrm{FeMo}_{6} \mathrm{O}_{18}\left\{\left(\mathrm{OCH}_{2}\right)_{3} \mathrm{CNH}_{2}\right\}_{2}\right] 2$ which was isolated as yellow crystals in $50 \%$ yield. Structural analysis by X-ray diffraction of single crystals (Table 1) revealed the expected $\delta$-type Anderson structure: the $\mathrm{Fe}^{\mathrm{III}}$ ion in the center of the six edge-sharing $\mathrm{MnO}_{6}$ octahedra is coordinated to the six alkoxo groups of two TRIS ligands. Selected bond distances and angles are compiled in

10 Table 2.

IR spectra of compounds $\mathbf{1}$ and 2, listed in the experimental part, are in agreement with their structures. ${ }^{[21 ; 33]}$ It has to be pointed out that they display a single, broad band around $700 \mathrm{~cm}^{-1}$ for the Mo-O-Mo bridges, in accordance with the central arrangement of both TRIS ligands ( $\delta$ structure). The $\chi$ structure would have two bands in this region. ${ }^{[21]}$

15 The reactions of nickel(II) acetate or zinc(II) acetate with $\left[\mathrm{N}\left(\mathrm{C}_{4} \mathrm{H}_{9}\right)_{4}\right]_{4}\left[\alpha-\mathrm{Mo}_{8} \mathrm{O}_{26}\right]$ and TRIS did not yield the expected Anderson-type compound. This result is in contrast to other tris(hydroxymethyl)methane derivatives that do form the functionalized Anderson-type POM with a central $\mathrm{Ni}^{\mathrm{II}}$ or $\mathrm{Zn}^{\mathrm{II}}{ }^{[21]}$ We therefore decided to vary the reaction conditions and to use a different molybdate source. From the reaction of zinc(II) acetate with $\left[\mathrm{N}\left(\mathrm{C}_{4} \mathrm{H}_{9}\right)_{4}\right]_{2}\left[\mathrm{Mo}_{2} \mathrm{O}_{7}\right]$ in the presence of TRIS, we isolated a compound with the molecular formula $\left[\mathrm{N}_{(}\left(\mathrm{C}_{4} \mathrm{H}_{9}\right)_{4}\right]_{2}\left[\mathrm{Mo}_{2} \mathrm{Zn}_{2} \mathrm{O}_{6}\{(\mathrm{O}-\right.$ $\left.\left.\left.\mathrm{CH}_{2}\right)_{2} \mathrm{C}\left(\mathrm{NH}_{2}\right) \mathrm{CH}_{2} \mathrm{OH}\right\}_{2}\left(\mathrm{CH}_{3} \mathrm{CO}_{2}\right)_{2}\right] 3$ in moderate yield (36\%). Structural analysis by single crystal X-ray diffraction (Table 1) revealed the molecular structure. Figure 2 shows a ball-and-stick representation of the anion. It has has no internal symmetry. One of the two molybdenum atoms (Mo1) has a distorted octahedral environment, whereas the other one (Mo2) displays distorted 25 tetrahedral coordination. Both molybdenum centres have two terminal oxo ligands. Mo1 is sharing 
three bridging alkoxo ligands with zinc, two with $\mathrm{Zn} 1$ and one with $\mathrm{Zn} 2$. A terminal alkoxo ligand is completing its coordination sphere. Mo2 is sharing one bridging oxo ligand with each zinc. The two zinc atoms also have different environments. Zn1 has a distorted trigonal-bipyramidal environment, whereas $\mathrm{Zn} 2$ displays distorted tetrahedral coordination. Each of them is bound to the amine function of a TRIS molecule and to a monodentate acetate ligand, and is connected by a $\mu$ oxo ligands to the Mo2 centre. The $\mu$-alkoxo bridges towards the octahedral molybdenum complete the coordination spheres. Thus, the two TRIS molecules are complexed by two oxygen atoms and the nitrogen, leaving one $\mathrm{OH}$ group of each TRIS free.

The compound $\mathbf{3}$ is not suitable as a building block for hybrid molecular materials. It seems not to be stable in solution, as suggested by ${ }^{1} \mathrm{H}$ NMR analysis in DMSO. The signals are broad, indicating a dynamic process with several compounds in equilibrium. However, it is important to point out that the amine group is bound to the zinc. Such a coordination mode might explain the impossibility to form the Anderson structure, as it prevents the incorporation of zinc into the molybdenum oxo framework. Based on the well established HSAB concept, ${ }^{[34]}$ it is not surprising that the soft $\mathrm{Zn}$ (II) cation is bound to the nitrogen donor, whereas the hard Mo(VI) centre has more affinity towards the oxygen donors. The same phenomenon is likely to play a role with nickel(II). Indeed, no Andersontype compound is isolated in the reaction of nickel(II) acetate with $\left[\mathrm{N}\left(\mathrm{C}_{4} \mathrm{H}_{9}\right)_{4}\right]_{4}\left[\alpha-\mathrm{Mo}_{8} \mathrm{O}_{26}\right]$ in the presence of TRIS, and only ill-defined mixtures of compounds are obtained.

\section{Elaborating remote binding sites}

The free amine groups on compounds $\mathbf{1}$ and $\mathbf{2}$ could serve as ligands for transition metal ions, and we are currently exploring this possibility. Furthermore, they can react with suitable organic substrates to elaborate different binding sites. With this perspective, we chose to form imines by the reaction with aldehydes. Imine formation is known to proceed under mild conditions compatible with the stability of POMs. 
The reaction of $\mathbf{1}$ with 2-pyridinecarbaldehyde affords the compound $\left[\mathrm{N}\left(\mathrm{C}_{4} \mathrm{H}_{9}\right)_{4}\right]_{3}-$ $\left[\mathrm{MnMo}_{6} \mathrm{O}_{18}\left\{\left(\mathrm{OCH}_{2}\right)_{3} \mathrm{CN}=\mathrm{C}\left(2-\mathrm{C}_{5} \mathrm{H}_{4} \mathrm{~N}\right)\right\}_{2}\right] 4$ which was isolated in $77 \%$ yield. The complex was characterized by single crystal X-ray diffraction. Crystallographic data are compiled in Table 1, and the molecular structure of the complex anion is represented in Figure 3. The polyoxomolybdate retains the Anderson structure of the parent compound 1. Bond distances and angles (Table 2) are very similar in both compounds. The 1,2-diimine function provides a new bidentate chelating site for transition metal ions on each side of the polyanion.

The reaction of $\mathbf{1}$ with 4-pyridinecarbaldehyde proceeds in the same manner to give the corresponding compound $\left[\mathrm{N}\left(\mathrm{C}_{4} \mathrm{H}_{9}\right)_{4}\right]_{3}\left[\mathrm{MnMo}_{6} \mathrm{O}_{18}\left\{\left(\mathrm{OCH}_{2}\right)_{3} \mathrm{CN}=\mathrm{C}\left(4-\mathrm{C}_{5} \mathrm{H}_{4} \mathrm{~N}\right)\right\}_{2}\right] \mathbf{5}$ in $70 \%$ yield. IR

10 and NMR studies show the similarity of compounds 4 and $\mathbf{5}$. Beside the typical vibrational bands for the Anderson-type core, they present a band for the imine function at 1643 and $1641 \mathrm{~cm}^{-1}$ respectively. In the ${ }^{1} \mathrm{H}$ NMR spectra, all signals are broadened by the presence of the paramagnetic $\mathrm{Mn}^{\mathrm{III}}$ center. The chemical shifts for the pyridine rings are in the normal range between 7 and 9 ppm (for details see Experimental Part), whereas the $\mathrm{CH}_{2} \mathrm{O}$ groups are highly deshielded due to the 15 closer proximity to the $\mathrm{Mn}^{\mathrm{III}}$ center. Nevertheless, they reflect also the imine formation. They are displayed at 52.5 and $53.9 \mathrm{ppm}$ in compounds $\mathbf{4}$ and $\mathbf{5}$ respectively, as compared to $61.1 \mathrm{ppm}$ in the free amine compound $\mathbf{1}$.

Compounds $\mathbf{4}$ and $\mathbf{5}$ differ only in the location of the pendant binding sites. Whereas complex $\mathbf{4}$ has two bidentate binding sites, complex 5 has only monodentate binding sites. This opens the way to vary the complexation of transition metals with respect to the type of metal ions bound and the stability of the complex formed. We are currently exploring these possibilities. Our first attempts to coordinate $\mathrm{Cu}^{\mathrm{II}}$ or $\mathrm{Pd}^{\mathrm{II}}$ complexes to the grafted ligands on compounds $\mathbf{4}$ and $\mathbf{5}$ gave very insoluble compounds. As our long term goal is the elaboration of defined structures in solution, we are now modifying the ligand part and the transition metal complex. Our flexible approach which allows the separate modification of each part is helpful in this respect. 


\section{Conclusion}

We have shown the possibility to incorporate the TRIS ligand into a heteropolymolybdate. The selfassembly of such a functionalized POM from several metal ions ( $\left.\mathrm{Mo}^{\mathrm{VI}}, \mathrm{Mn}^{\mathrm{III}}, \mathrm{Fe}^{\mathrm{III}}\right)$ and several

5 ligands (oxo, alkoxo) is a highly complex process relying on the molecular recognition of all the components. Their steric and electronic complementarity allows the formation of the expected structure in high yield. The affinity of $\mathrm{Zn}^{\mathrm{II}}$ and $\mathrm{Ni}^{\mathrm{II}}$ for nitrogen is incompatible with the preference of $\mathrm{Mo}^{\mathrm{VI}}$ for oxo and alkoxo ligands, therefore disrupting the formation of the Anderson structure. As a result, mixtures of compounds are present in solutions of molybdate, TRIS and $\mathrm{Zn}^{\mathrm{II}}$ or $\mathrm{Ni}^{\mathrm{II}}$. It was possible to isolate one compound (3) of such a mixture in the solid state. This compound is representative for all the fragments which are presumably present in solution: it contains tetra- and hexacoordinated molybdenum with only $\mathrm{O}$ donor atoms, and tetra- and pentacoordinated zinc with $\mathrm{N}$ and $\mathrm{O}$ ligands.

15 The grafted ligands on the POM can be modified by organic reactions. ${ }^{[35]}$ The elaboration of binding sites presented here is only one aspect of this chemistry, and it is clear that other functions can be introduced in the same way. That is the advantage of this flexible approach where the synthesis of the POM core and the introduction of a specific function are two distinct steps. We are exploring this field by varying separately the POM (molybdates, vanadates, ...) and the function (metal binding, hydrogen bonding, targeting biological substances, ...).

\section{Experimental Section}

\section{General Remarks:}

$\left(\mathrm{N}\left(\mathrm{C}_{4} \mathrm{H}_{9}\right)_{4}\right)_{4}\left[\alpha-\mathrm{Mo}_{8} \mathrm{O}_{26}\right]$ was prepared by literature methods. ${ }^{[36]}$ All other compounds, including 25 solvents, were commercially available as reagent grade and used as received. Elemental analysis 
were performed by the "Service de microanalyse", Université Pierre et Marie Curie, Paris, France and by the "Service central d'analyse", CNRS, Vernaison, France.

\section{Spectroscopy}

NMR spectra $\left({ }^{1} \mathrm{H},{ }^{13} \mathrm{C}\right)$ were recorded on a Bruker AC300 spectrometer at $300 \mathrm{MHz}$ and $75.5 \mathrm{MHz}$ respectively. Deuteriated solvent $\left(\mathrm{CD}_{3} \mathrm{CN}\right.$ unless otherwise stated) was used. Chemical shifts $\delta$ are expressed in ppm relative to $\mathrm{Me}_{4} \mathrm{Si}$, the downfield direction being positive, with residual solvent peak as standard. ${ }^{13} \mathrm{C}$ NMR was recorded using an INEPT pulsing sequence. Assignment of signals is quoted with respect to numbering within the molecular fragments: pyr stands for the pyridine rings, $T B A$ stands for the tetrabutylammonium cations.

10 IR spectra were obtained in $\mathrm{KBr}$ pellets on a Bio-Rad FTS 165 spectrometer. Relative intensities are given after the wavenumber as vs $=$ very strong, $\mathrm{s}=$ strong, $\mathrm{m}=$ medium, $\mathrm{w}=$ weak, $\mathrm{sh}=$ shoulder, br $=$ broad

\section{X-ray Crystal Structure Determination}

A selected single crystal was set up on an automatic diffractometer Mach3 Enraf Nonius. Unit cell dimensions with estimated standard deviations were obtained from least-squares refinements of the setting angles of 25 well-centered reflections. Two standard reflections were monitored periodically; for compounds 1, 2 and 4 (18, 38 and $22 \%$ decay respectively) the data were accordingly scaled. Crystallographic data and other pertinent information are summarized in Table 1. Corrections were made for Lorentz and polarization effects. Secondary extinction corrections were necessary only for compound 2 .

Computations were performed by using the PC version of CRYSTALS. ${ }^{[37]}$ Atomic form factors for neutral atoms were taken from tabulated values. ${ }^{[38]}$ Real and imaginary parts of anomalous dispersion were taken into account. The structure was solved by direct methods ${ }^{[39]}$ and successive Fourier maps. An absorption correction (based on a Psi-scan curve for 1, using DIFABS ${ }^{[40]}$ for other compounds) was applied. 
For 1 and 2 non-hydrogen atoms were anisotropically refined except for the carbon atoms of the half cation contained in the asymmetric unit which presents some disorder and for the oxygen atoms of the water molecules (compound 1). Restraints were applied to the carbon-carbon distances in both cations and hydrogen atoms were not introduced. For $\mathbf{3}$ all non hydrogen atoms were anisotropically refined. Application of restraints to one of the two acetate ligands was necessary. Hydrogen $(\mathrm{C}-\mathrm{H})$ atoms were introduced in calculated positions. For $\mathbf{4}$ because of the few observed reflections only manganese, molybdenum and oxygen atoms were anisotropically refined. Restraints were applied to the carbon-carbon distances of the cations and no hydrogen atoms were introduced. In all cases least square refinements in full matrix were carried out by minimizing the 10 function $\sum w\left(\left|F_{o}\right|-\left|F_{c}\right|\right)^{2}$ where $F_{o}$ and $F_{c}$ are the observed and calculated structure factors. Models reached convergence with $R=\Sigma\left(|| F_{o}|-| F_{c} \mid\right) / \Sigma w F_{o}$ and $R_{w}=\left[\Sigma w\left(\left|F_{o}\right|-\left|F_{c}\right|\right)^{2} / \Sigma w\left(F_{o}\right)^{2}\right]^{1 / 2}$ having values listed in Table 1.

In the last stages of the refinement, each reflection was assigned a weight: $w=w^{\prime}\left\{1-\left[\left(|| F_{o}|-| F_{c} \mid\right) / 6 \sigma\left|F_{o}\right|\right]^{2}\right\}^{2}$ with $w^{\prime}=1 / \Sigma_{r} A_{r} T_{r}(X)$ with three coefficients for a Chebyshev

15 series, for which $X=F_{c} / F_{c(\max )}$.

Criteria for a satisfactory complete analysis were the ratio of rms shift to standard deviations being less then 0.2 (except for 2 , due to the restraints applied to the acetate ion, the value is 0.8 ) and no significant features in the difference Fourrier map.

Crystallographic data (excluding structure factors) for the structures reported in this paper have 20 been deposited with the Cambridge Crystallographic Data Centre as supplementary publication nos. CCDC-189392 (1), -189393 (2), -189394 (3) and -189395 (4). Copies of the data can be obtained free of charge on application to the CCDC, 12 Union Road, Cambridge CB2 1EZ, U.K. [Fax: (internat.)+44-1223/336-033; E-mail: deposit@ccdc.cam.ac.uk].

\section{Synthesis and characterization}




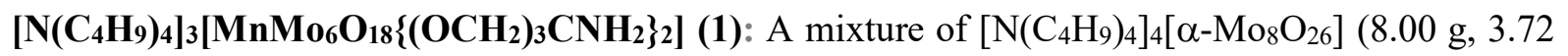
mmol) with $\mathrm{Mn}\left(\mathrm{CH}_{3} \mathrm{COO}\right)_{3} \cdot 2 \mathrm{H}_{2} \mathrm{O}(1.49 \mathrm{~g}, 5.56 \mathrm{mmol})$ and $\left(\mathrm{HOCH}_{2}\right)_{3} \mathrm{CNH}_{2}(1.56 \mathrm{~g}, 12.8 \mathrm{mmol})$ in $150 \mathrm{~mL}$ of acetonitrile was refluxed for $16 \mathrm{~h}$. The orange solution was cooled to room temperature and filtered to remove a very fine black solid. The filtrate was exposed to ether vapors. After $2 \mathrm{~h}, \mathrm{a}$

5 white precipitate was filtered off. The orange filtrate was exposed again to ether vapors for several days. Large orange crystals were obtained. They were isolated by filtration, washed with a small amount of acetonitrile and then ether, and dried under vacuum. Yield $7.42 \mathrm{~g}(80 \%)$.

$\mathrm{C}_{56} \mathrm{H}_{124} \mathrm{Mo}_{6} \mathrm{MnN}_{5} \mathrm{O}_{24}$ (1882.21): calcd. C 35.74, H 6.64, Mo 30.58, Mn 2.92, N 3.72; found C 35.73, H 6.72, Mo 29.04, Mn 2.75, N 3.54.

10 IR: nu(tilde) $)_{\max }=3290\left(v_{\text {as }} \mathrm{NH}, \mathrm{w}\right), 2961(v \mathrm{CH}, \mathrm{s}), 2936(v \mathrm{CH}, \mathrm{s}), 2875(v \mathrm{CH}, \mathrm{s}), 1611(\mathrm{w}), 1480$ ( $\delta \mathrm{CH}, \mathrm{s}), 1384(\delta \mathrm{CH}, \mathrm{m}), 1348(\mathrm{w}), 1256(\mathrm{w}), 1151(\mathrm{w}), 1129(\mathrm{w}), 1108$ (v CO, m), $1040(v \mathrm{CO}$, s), $939(v$ Mo=O, s), $919(v$ Mo=O, s), $902(v \mathrm{Mo}=\mathrm{O}, \mathrm{s}), 797(\mathrm{w}), 737(\mathrm{w}), 663$ (v Mo-O-Mo, vs), $563(\mathrm{~m}), 520(\mathrm{w}), 461(\mathrm{~m}), 413(\mathrm{~m}), 368(\mathrm{~s}), 321(\mathrm{~m}), 282(\mathrm{w})$.

${ }^{1} \mathrm{H}$ NMR ([D 6 DMSO) $\delta=0.93\left(\mathrm{t},{ }^{3} J=7.3 \mathrm{~Hz}, 36 \mathrm{H}, 4-\mathrm{H}_{T B A}\right), 1.31\left(\mathrm{sx},{ }^{3} J=7.3 \mathrm{~Hz}, 24 \mathrm{H}, 3-\mathrm{H}_{T B A}\right)$, $151.57\left(\mathrm{~m}, 24 \mathrm{H}, 2-\mathrm{H}_{T B A}\right), 3.16\left(\mathrm{~m}, 24 \mathrm{H}, 1-\mathrm{H}_{T B A}\right), 61.1\left(\mathrm{~s}, 12 \mathrm{H}, \mathrm{CH}_{2} \mathrm{O}\right)$.

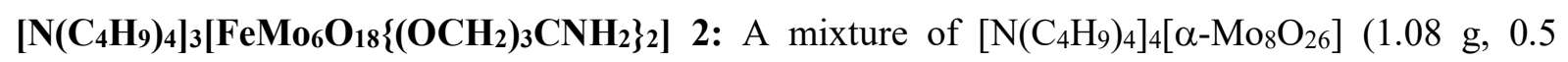
mmol) with $\mathrm{Fe}(\mathrm{acac})_{3}(265 \mathrm{mg}, 0.75 \mathrm{mmol}$, acac = acetylacetonate $)$ and $\left(\mathrm{HOCH}_{2}\right)_{3} \mathrm{CNH}_{2}(182 \mathrm{mg}$, $1.5 \mathrm{mmol}$ ) in $20 \mathrm{~mL}$ of acetonitrile was refluxed for $16 \mathrm{~h}$. The red suspension was cooled to room

20 temperature, and a yellow-orange solid was removed by filtration. The red filtrate was exposed to ether vapors. After three days, a microcrystalline solid is isolated by filtration. The compound was recrystallized from DMF to obtain analytical pure 2 with 2 molecules of DMF. Yield $615 \mathrm{mg}$ (49\%). Crystals suitable for X-ray diffraction were grown by slow ether diffusion into an acetonitrile solution. 
$\mathrm{C}_{62} \mathrm{H}_{138} \mathrm{FeMo}_{6} \mathrm{~N}_{7} \mathrm{O}_{26}$ (2029.31) calcd. C 36.70, H 6.85, Fe 2.75, Mo 28.37, N 4.83; found C 36.01, H 6.80, Fe 2.17, Mo 28.07, N 4.65.

IR: nu(tilde $)_{\max }=2961(v \mathrm{CH}, \mathrm{s}), 2935(v \mathrm{CH}, \mathrm{s}), 2874(v \mathrm{CH}, \mathrm{s}), 1654(\mathrm{w}), 1482(\delta \mathrm{CH}, \mathrm{m}), 1382$

$(\delta \mathrm{CH}, \mathrm{w}), 1153(\mathrm{w}), 1129(\mathrm{w}), 1041(v \mathrm{CO}, \mathrm{s}), 938(v \mathrm{Mo}=\mathrm{O}, \mathrm{vs}), 920(v \mathrm{Mo}=\mathrm{O}, \mathrm{vs}), 902$ (

$5 \mathrm{Mo}=\mathrm{O}, \mathrm{vs}), 802(\mathrm{w}), 665(\mathrm{v}$ Mo-O-Mo, br, vs), $613(\mathrm{w}), 562(\mathrm{~m}), 528(\mathrm{w}), 487(\mathrm{w}), 450(\mathrm{w}), 410$ (w), $367(\mathrm{~m}), 324(\mathrm{~m}), 278(\mathrm{w})$.

$\left[\mathrm{N}\left(\mathrm{C}_{4} \mathrm{H}_{9}\right)_{4}\right]_{2}\left[\mathrm{Mo}_{2} \mathrm{Zn}_{2} \mathrm{O}_{6}\left\{\left(\mathrm{OCH}_{2}\right) \mathrm{C}\left(\mathrm{NH}_{2}\right) \mathrm{CH}_{2} \mathrm{OH}\right\}_{2}\left(\mathrm{CH}_{3} \mathrm{CO}_{2}\right)_{2}\right] \quad 3:$ A solution of $\left[\mathrm{N}\left(\mathrm{C}_{4} \mathrm{H}_{9}\right)_{4}\right]_{2}\left[\mathrm{Mo}_{2} \mathrm{O}_{7}\right](1.58 \mathrm{~g}, 2 \mathrm{mmol}), \mathrm{Zn}\left(\mathrm{CH}_{3} \mathrm{CO}_{2}\right)_{2}(878 \mathrm{mg}, 4 \mathrm{mmol})$ and $\left(\mathrm{HOCH}_{2}\right)_{3} \mathrm{CNH}_{2}(485$ $10 \mathrm{mg}, 4 \mathrm{mmol}$ ) in $20 \mathrm{~mL}$ of acetonitrile was heated to reflux. After $20 \mathrm{~min}$, the mixture became cloudy. After $16 \mathrm{~h}$, the reaction mixture was filtered while hot. The filtrate was cooled to room temperature and exposed to ether vapors. Over a period of two months, colorless crystals formed. They were isolated by filtration and dried under vacuum. Yield $0.91 \mathrm{~g}(36 \%)$.

$\mathrm{C}_{44} \mathrm{H}_{96} \mathrm{Mo}_{2} \mathrm{~N}_{4} \mathrm{O}_{16} \mathrm{Zn}_{2}$ (1259.91) calcd. C 41.95, H 7.68, N 4.45; found C 42.05, H 7.69, N 4.60.

15 IR: nu(tilde) $)_{\max }=2962(v \mathrm{CH}, \mathrm{s}), 2936(v \mathrm{CH}, \mathrm{s}), 2876(v \mathrm{CH}, \mathrm{s}), 2849(\mathrm{~s}, \mathrm{sh}), 2875(\mathrm{w}), 1615(\mathrm{~s})$, 1586 (s, sh), $1486(\delta \mathrm{CH}, \mathrm{s}), 1460(\delta \mathrm{CH}, \mathrm{m}), 1418(\mathrm{~m}, \mathrm{sh}), 1381(\delta \mathrm{CH}, \mathrm{s}), 1326(\mathrm{~m}), 1278(\mathrm{w})$, 1153 (m), 1104 (m, sh), 1088 (s, sh), 1075 (s), 1020 (v CO, s), 972 (s), 939 (w, sh), 913 (v Mo=O, vs), $890(\mathrm{v} \mathrm{Mo}=\mathrm{O}, \mathrm{vs}), 847$ ( $\mathrm{v} \mathrm{Mo}=\mathrm{O}, \mathrm{vs}), 825$ (vs, sh), $792(\mathrm{~m}, \mathrm{sh}), 739(\mathrm{w}), 671(\mathrm{~m}), 662(\mathrm{~m}), 615$ (w), $561(\mathrm{w}), 525(\mathrm{~m}), 449(\mathrm{w}), 421(\mathrm{w}), 336(\mathrm{w}), 330(\mathrm{w}), 292(\mathrm{w})$.

${ }^{1} \mathrm{H}$ NMR $\left(\left[\mathrm{D}_{6}\right] \mathrm{DMSO}, 80^{\circ} \mathrm{C}\right) \delta=0.95\left(\mathrm{t},{ }^{3} \mathrm{~J}=7.0 \mathrm{~Hz}, 24 \mathrm{H}, 4-\mathrm{H}_{T B A}\right), 1.36\left(\mathrm{~m}, 16 \mathrm{H}, 3-\mathrm{H}_{T B A}\right), 1.63$ $\left(\mathrm{q},{ }^{3} \mathrm{~J}=7.5 \mathrm{~Hz}, 16 \mathrm{H}, 2-\mathrm{H}_{T B A}\right), 1.78\left(\mathrm{~s}, 6 \mathrm{H}, \mathrm{CH}_{3} \mathrm{CO}_{2}\right), 3.22\left(\mathrm{~m}, 16 \mathrm{H}, 1-\mathrm{H}_{T B A}\right), 3.5$ (br), 4.0 (br), 4.1 (br), 4.2 (br).

${ }^{13} \mathrm{C}$ NMR $\left(\left[\mathrm{D}_{6}\right] \mathrm{DMSO}, 80^{\circ} \mathrm{C}\right) \delta=13.5\left(4-\mathrm{C}_{T B A}\right), 19.2\left(3-\mathrm{C}_{T B A}\right), 23.1\left(2-\mathrm{C}_{T B A}\right), 23.8\left(\underline{\mathrm{CH}}_{3} \mathrm{COO}\right)$, $56.7,57.5\left(1-\mathrm{C}_{T B A}\right), 64.1,70.8,78.9,79.2,171.5,176.1$. 
$\left[\mathbf{N}\left(\mathrm{C}_{4} \mathrm{H}_{9}\right)_{4}\right]_{3}\left[\mathrm{MnMo6}_{6} \mathrm{O}_{18}\left\{\left(\mathrm{OCH}_{2}\right)_{3} \mathbf{C N}=\mathbf{C}\left(2-\mathrm{C}_{5} \mathrm{H}_{4} \mathbf{N}\right)\right\}_{2}\right] \quad 4: \quad$ 2-pyridinecarbaldehyde $(330 \mu \mathrm{L}, 3.5$ mmol) and acetic acid $(9 \mu \mathrm{L}, 0.16 \mathrm{mmol})$ were added to a boiling solution of $\mathbf{1}(3.00 \mathrm{~g}, 1.59 \mathrm{mmol})$ in $100 \mathrm{~mL}$ of methanol. After $10 \mathrm{~min}$, an orange solid started to precipitate. The mixture was heated to reflux for further $3.5 \mathrm{~h}$. After cooling to room temperature, a methanolic solution of

$5\left[\mathrm{~N}\left(\mathrm{C}_{4} \mathrm{H}_{9}\right)_{4}\right](\mathrm{OH})\left(\mathrm{c}=5.09 \cdot 10^{-3} \mathrm{M}, 34 \mathrm{~mL}, 0.16 \mathrm{mmol}\right)$ was added and the orange precipitate was isolated by filtration, washed with methanol and dried under vacuum. Yield $2.54 \mathrm{~g}(77 \%)$.

$\mathrm{C}_{68} \mathrm{H}_{130} \mathrm{MnMo}_{6} \mathrm{O}_{24} \mathrm{~N}_{7}$ (2060.40) calcd. C 39.64, H 6.36, N 4.76; found C 39.58, H 6.47, N 4.89.

${ }^{1} \mathrm{H}$ NMR $\left(67^{\circ} \mathrm{C}\right) \delta=0.99\left(\mathrm{br}, 36 \mathrm{H}, 4-\mathrm{H}_{T B A}\right), 1.41\left(\mathrm{br}, 24 \mathrm{H}, 3-\mathrm{H}_{T B A}\right), 1.65\left(\mathrm{br}, 24 \mathrm{H}, 2-\mathrm{H}_{T B A}\right), 3.14$ (br, $\left.24 \mathrm{H}, 1-\mathrm{H}_{T B A}\right), 7.20$ (s, $\left.\left.2 \mathrm{H}, 5-\mathrm{H}_{p y r}\right), 7.88\left(\mathrm{~s}, 4 \mathrm{H}, 3-\mathrm{H}_{p y r}\right), 4-\mathrm{H}_{p y r}\right), 8.45(\mathrm{~s}, 2 \mathrm{H}, \mathrm{pyrCH}=\mathrm{N}), 8.68$ $10\left(\mathrm{~s}, 2 \mathrm{H}, 6-\mathrm{H}_{p y r}\right), 54.4\left(\mathrm{~s}, 12 \mathrm{H}, \mathrm{CH}_{2} \mathrm{O}\right) .\left([\mathrm{D} 6] \mathrm{DMSO}, 80^{\circ} \mathrm{C}\right) \delta=0.93\left(\mathrm{t},{ }^{3} \mathrm{~J}=7.6 \mathrm{~Hz}, 36 \mathrm{H}, 4-\mathrm{H}_{T B A}\right)$, $1.34\left(\mathrm{~m},{ }^{3} J=7.6 \mathrm{~Hz}, 24 \mathrm{H}, 3-\mathrm{H}_{T B A}\right), 1.61\left(\mathrm{~m}, 24 \mathrm{H}, 2-\mathrm{H}_{T B A}\right), 3.18\left(\mathrm{~m}, 24 \mathrm{H}, 1-\mathrm{H}_{T B A}\right), 7.28(\mathrm{br}, 2 \mathrm{H}$, 5- $\left.\mathrm{H}_{p y r}\right), 7.84$ (br, $\left.2 \mathrm{H}, 4-\mathrm{H}_{p y r}\right), 7.94$ (br, $\left.2 \mathrm{H}, 3-\mathrm{H}_{p y r}\right), 8.24$ (br, $\left.2 \mathrm{H}, \mathrm{pyrCH}=\mathrm{N}\right), 8.72$ (br, $2 \mathrm{H}, 6-$ $\left.\mathrm{H}_{\text {pyr }}\right), 52.5$ (br, $\left.12 \mathrm{H}, \mathrm{CH}_{2} \mathrm{O}\right)$.

${ }^{13} \mathrm{C}$ NMR ([D6]DMSO, 80 $\left.{ }^{\circ} \mathrm{C}\right) \delta=12.82\left(4-\mathrm{C}_{T B A}\right), 18.79\left(3-\mathrm{C}_{T B A}\right), 22.78\left(2-\mathrm{C}_{T B A}\right), 57.71\left(1-\mathrm{C}_{T B A}\right)$,

$15121.6\left(5-\mathrm{C}_{p y r}\right), 125.7\left(3-\mathrm{C}_{p y r}\right), 135.8\left(4-\mathrm{C}_{p y r}\right), 148.0\left(2-\mathrm{C}_{p y r}\right), 151.6\left(6-\mathrm{C}_{p y r}\right), 198.0(\mathrm{pyrCH}=\mathrm{N})$.

IR: nu(tilde $)_{\max }=2961(v \mathrm{CH}, \mathrm{s}), 2936(v \mathrm{CH}, \mathrm{s}), 2875(v \mathrm{CH}, \mathrm{s}), 1643(\mathrm{C}=\mathrm{N}, \mathrm{m}), 1584(\mathrm{Ar}, \mathrm{w})$, 1567 (Ar, w), $1482(\delta \mathrm{CH}, \mathrm{s}), 1469(\delta \mathrm{CH}, \mathrm{m}), 1381(\delta \mathrm{CH}, \mathrm{m}), 1345(\mathrm{w}), 1262(\mathrm{w}), 1152(\mathrm{w})$, $1095(\mathrm{w}), 1088(\mathrm{w}), 1026(v \mathrm{CO}, \mathrm{s}), 992(\mathrm{w}), 941(v \mathrm{Mo}=\mathrm{O}, \mathrm{s}), 921(v \mathrm{Mo}=\mathrm{O}, \mathrm{s}), 904(v \mathrm{Mo}=\mathrm{O}, \mathrm{s})$, 803 (w), 782 (w), 664 (v Mo-O-Mo, vs), 592 (w), 562 (m), 463 (m), 410 (m), 366 (s), 321 (m), 260 $20(\mathrm{~m})$.

$\left[\mathbf{N}\left(\mathrm{C}_{4} \mathrm{H}_{9}\right)_{4}\right]_{3}\left[\mathrm{MnMo6}_{6} \mathrm{O}_{18}\left\{\left(\mathrm{OCH}_{2}\right)_{3} \mathbf{C N}=\mathbf{C}\left(\mathbf{4}_{-} \mathrm{C}_{5} \mathrm{H}_{4} \mathrm{~N}\right)\right\}_{2}\right]$ 5: The compound was obtained as an orange solid by the same procedure as for $\mathbf{4}$. Compound $\mathbf{5}$ is more soluble than $\mathbf{4}$. Yield $2.23 \mathrm{~g}$ $(70 \%)$.

$25 \mathrm{C}_{68} \mathrm{H}_{130} \mathrm{MnMo}_{6} \mathrm{O}_{24} \mathrm{~N}_{7}$ (2060.40) calcd. C 39.64, H 6.36, N 4.76; found C 39.41, H 6.47, N 4.77. 
${ }^{1} \mathrm{H}$ NMR $\left(67^{\circ} \mathrm{C}\right) \delta=0.98\left(\mathrm{br}, 36 \mathrm{H}, 4-\mathrm{H}_{T B A}\right), 1.41\left(\mathrm{br}, 24 \mathrm{H}, 3-\mathrm{H}_{T B A}\right), 1.66\left(\mathrm{br}, 24 \mathrm{H}, 2-\mathrm{H}_{T B A}\right), 3.17$ (br, $\left.24 \mathrm{H}, 1-\mathrm{H}_{T B A}\right), 7.56$ (br, $\left.4 \mathrm{H}, 3-\mathrm{H}_{p y r}, 6-\mathrm{H}_{p y r}\right), 8.41$ (br, $\left.2 \mathrm{H}, \mathrm{pyrCH}=\mathrm{N}\right), 8.68$ (br, $4 \mathrm{H}, 4-\mathrm{H}_{p y r}, 5-$ $\left.\mathrm{H}_{\text {pyr }}\right), 53.9$ (br, $\left.12 \mathrm{H}, \mathrm{CH}_{2} \mathrm{O}\right)$.

${ }^{13} \mathrm{C}$ NMR ([D6]DMSO) $\delta=13.60\left(4-\mathrm{C}_{T B A}\right), 19.33\left(3-\mathrm{C}_{T B A}\right), 23.07\left(2-\mathrm{C}_{T B A}\right), 57.50\left(1-\mathrm{C}_{T B A}\right), 123.6$

$5 \quad\left(3-\mathrm{C}_{p y r}, 6-\mathrm{C}_{p y r}\right), 136.1\left(2-\mathrm{C}_{p y r}\right), 149.4\left(4-\mathrm{C}_{p y r}, 5-\mathrm{C}_{p y r}\right), 197.6(\mathrm{pyrCH}=\mathrm{N}), 217.3\left(\mathrm{CH}_{2} \mathrm{O}\right)$.

IR: nu(tilde $)_{\max }=2961(v \mathrm{CH}, \mathrm{s}), 2935(v \mathrm{CH}, \mathrm{s}), 2874(v \mathrm{CH}, \mathrm{s}), 1641(\mathrm{C}=\mathrm{N}, \mathrm{m}), 1597(\mathrm{Ar}, \mathrm{m})$, 1559 (Ar, m), 1480 ( $\delta \mathrm{CH}, \mathrm{s}), 1467$ ( $\delta \mathrm{CH}, \mathrm{m}), 1408(\mathrm{~m}), 1381(\delta \mathrm{CH}, \mathrm{m}), 1348(\mathrm{w}), 1322(\mathrm{w}), 1232$ (w), $1170(w), 1153(w), 1094(w), 1084(w), 1026$ ( $v$ CO, s), $940(v$ Mo=O, s), 921 ( $v$ Mo=O, s), $903(v$ Mo=O, s), $818(w), 803(w), 736(w), 664$ ( $v$ Mo-O-Mo, vs), $563(\mathrm{~m}), 521(\mathrm{w}), 465(\mathrm{~m}), 410$ $10 \quad(\mathrm{~m}), 367(\mathrm{~s}), 322(\mathrm{~m})$.

\section{Acknowledgments}

We would like to acknowledge the support from the Pierre and Marie Curie University and the 15 CNRS. 
((Captions:))

Table 1. Crystal data and structure refinement for compounds $\mathbf{1 , 2 , 3}$ and 4.

5 Table 2. Selected bond lengths and angles for the anions in 1, 2 and 4.

Figure 1. Structure of the anion of 1: [ $\left.\mathrm{MnMo}_{6} \mathrm{O}_{18}\left\{\left(\mathrm{OCH}_{2}\right)_{3} \mathrm{CNH}_{2}\right\}_{2}\right]^{3-}$. The TRIS ligands cap both 10 sides of the Anderson structure.

Figure 2. Ball-and-stick representation of the anion of 3:

$\left[\mathrm{Mo}_{2} \mathrm{Zn}_{2} \mathrm{O}_{6}\left\{\left(\mathrm{OCH}_{2}\right) \mathrm{C}\left(\mathrm{NH}_{2}\right) \mathrm{CH}_{2} \mathrm{OH}\right\}_{2}\left(\mathrm{CH}_{3} \mathrm{CO}_{2}\right)_{2}\right]^{2-}$. Note the coordination of the amine groups to zinc.

15

Figure 3. Structure of the anion of 4: $\left[\mathrm{MnMo}_{6} \mathrm{O}_{18}\left\{\left(\mathrm{OCH}_{2}\right)_{3} \mathrm{CN}=\mathrm{C}\left(2-\mathrm{C}_{5} \mathrm{H}_{4} \mathrm{~N}\right)\right\}_{2}\right]^{3-}$. A chelating binding site is displayed at both sides of the Anderson structure.

20 \{Insert optional text to be placed underneath the Graphical Abstract (Table of Contents). 
((Tables))

Table 1.

\begin{tabular}{|c|c|c|c|c|}
\hline Compound & 1 & 2 & 3 & 4 \\
\hline Empirical formula & $\mathrm{C}_{56} \mathrm{H}_{124} \mathrm{MnMo}_{6} \mathrm{~N}_{5} \mathrm{O}_{26}$ & $\mathrm{C}_{56} \mathrm{H}_{124} \mathrm{FeMo}_{6} \mathrm{~N}_{5} \mathrm{O}_{24}$ & $\mathrm{C}_{46} \mathrm{H}_{99} \mathrm{Mo}_{2} \mathrm{~N}_{5} \mathrm{O}_{16} \mathrm{Zn}_{2}$ & $\mathrm{C}_{68} \mathrm{H}_{130} \mathrm{MnMo}_{6} \mathrm{~N}_{7} \mathrm{O}_{24}$ \\
\hline Formula mass & 1914.2 & 1883.1 & 1301.0 & 2060.4 \\
\hline $\mathrm{a}[\AA]$ & $14.650(4)$ & $25.845(11)$ & $13.690(3)$ & $23.243(4)$ \\
\hline $\mathrm{b}[\AA]$ & $24.245(9)$ & $24.518(13)$ & $14.634(4)$ & $14.298(3)$ \\
\hline $\mathrm{c}[\AA]$ & $24.453(10)$ & $14.649(12)$ & $18.037(11)$ & $27.595(4)$ \\
\hline$\alpha\left[^{\circ}\right]$ & 90 & 90 & $75.31(4)$ & 90 \\
\hline$\beta\left[^{\circ}\right]$ & 90 & $101.55(6)$ & $86.11(4)$ & $99.28(1)$ \\
\hline$\gamma\left[^{\circ}\right]$ & 90 & 90 & $62.69(2)$ & 90 \\
\hline $\mathrm{V}\left[\AA^{3}\right]$ & $8685(5)$ & 9706(9) & $3101(2)$ & $9051(3)$ \\
\hline Z & 4 & 4 & 2 & 4 \\
\hline Crystal system & Orthorhombic & Monoclinic & Triclinic & Monoclinic \\
\hline Space group & $\mathrm{Pcmn}$ & $\mathrm{C} 2 / \mathrm{m}$ & $\mathrm{P}-1$ & $\mathrm{P} 21 / \mathrm{c}$ \\
\hline Crystal colour & orange & yellow & none & orange \\
\hline Linear abs. coef. $\mu\left[\mathrm{cm}^{-1}\right]$ & 10.2 & 9.9 & 12.3 & 9.8 \\
\hline$D_{\text {calc }}\left[\mathrm{g} \cdot \mathrm{cm}^{-3}\right]$ & 1.46 & 1.38 & 1.39 & 1.51 \\
\hline Radiation & Mo-K $\alpha(0.71069 \AA)$ & Mo-K $\alpha(0.71069 \AA)$ & Mo-K $\alpha(0.71069 \AA)$ & Mo-K $\alpha(0.71069 \AA)$ \\
\hline Scan mode & $\omega / 2 \theta$ & $\omega / 2 \theta$ & $\omega / 2 \theta$ & $\omega / 2 \theta$ \\
\hline Scan range $\left[^{\circ}\right]$ & $0.80+0.345 \tan (\theta)$ & $0.80+0.345 \tan (\theta)$ & $0.80+0.345 \tan (\theta)$ & $0.80+0.345 \tan (\theta)$ \\
\hline$\theta$ range $\left[^{\circ}\right]$ & $1-25$ & $1-26$ & $1-28$ & $1-25$ \\
\hline Temperature[K] & 221 & 295 & 295 & 295 \\
\hline hkl range & 0,$17 ; 0,28 ; 0,29$ & 0,$31 ; 0,30 ;-18,17$ & 0,$18 ;-17,19 ;-23,23$ & 0,$27 ; 0,16 ;-32,32$ \\
\hline $\mathrm{Nb}$. of data collected & 8355 & 9343 & 15540 & 17021 \\
\hline $\mathrm{Nb}$. of unique data & 7813 & 9132 & 14920 & 15879 \\
\hline $\mathrm{R}_{\mathrm{int}}$ & none & 0.03 & 0.04 & 0.05 \\
\hline $\mathrm{Nb}$. of data in refinement & $2998\left(\mathrm{~F}_{\mathrm{o}}\right)^{2}>3 \sigma\left(\mathrm{F}_{\mathrm{o}}\right)^{2}$ & $4048\left(\mathrm{~F}_{\mathrm{o}}\right)^{2}>3 \sigma\left(\mathrm{F}_{\mathrm{o}}\right)^{2}$ & $8070\left(\mathrm{~F}_{\mathrm{o}}\right)^{2}>3 \sigma\left(\mathrm{F}_{\mathrm{o}}\right)^{2}$ & $4248\left(\mathrm{~F}_{\mathrm{o}}\right)^{2}>2 \sigma\left(\mathrm{F}_{\mathrm{o}}\right)^{2}$ \\
\hline Absorption correction & Psi-Scan & DIFABS & DIFABS & DIFABS \\
\hline $\mathrm{T}_{\min }, \mathrm{T}_{\max }$ & $0.72,1$ & $0.71,1$ & $0.93,1$ & $0.94,1$ \\
\hline $\mathrm{Nb}$. of variables & 413 & 410 & 650 & 580 \\
\hline Final R & 0.0620 & 0.0950 & 0.0458 & 0.0718 \\
\hline Final $\mathrm{R}_{\mathrm{w}}$ & 0.0713 & 0.116 & 0.0568 & 0.0791 \\
\hline Goodness of fit & 1.04 & 1.00 & 1.03 & 1.10 \\
\hline Extinction coefficient & none & 192 & none & none \\
\hline$\Delta \rho_{\max }\left[\mathrm{e} / \AA^{3}\right]$ & $-0.70,+1.13$ & $-0.84,+1.29$ & $-0.56,+0.79$ & $-0.76,+0.97$ \\
\hline
\end{tabular}


Table 2.

\begin{tabular}{llll}
\hline \multicolumn{1}{c}{1} & \multicolumn{1}{c}{$\mathbf{2}$} & \multicolumn{1}{c}{4} \\
\hline $\begin{array}{l}\text { Distances } \\
\text { Mo-O }{ }_{\text {terminal }}\end{array}$ & $1.693(10)-1.718(10)$ & $1.650(9)-1.720(14)$ & $1.649(17)-1.703(13)$ \\
Mo-O $_{\text {bridge }}$ & $1.904(9)-1.925(9)$ & $1.892(29)-1.925(11)$ & $1.882(16)-1.952(13)$ \\
Mo-O $_{\text {alkoxo }}$ & $2.341(7)-2.403(7)$ & $2.341(44)-2.360(8)$ & $2.328(17)-2.415(13)$ \\
M-O $^{[a]}$ & $1.943(8)-2.031(12)$ & $1.971(8)-1.991(27)$ & $1.948(16)-1.992(13)$ \\
& & & \\
Angles O-M-O & & & \\
same TRIS & $92.05(22)-92.88(30)$ & $91.92(31)-92.84(22)$ & $91.92(51)-93.40(50)$ \\
opposite TRIS, cis & $87.18(32)-88.10(22)$ & $87.16(22)-88.08(31)$ & $86.67(52)-88.02(53)$ \\
opposite TRIS, trans & $179.42(31)-179.78(49)$ & $180.00(37)$ & $178.99(56)-179.93(51)$ \\
\hline
\end{tabular}

${ }^{[\mathrm{a}]} \mathrm{M}=\mathrm{Mn}(\mathbf{1}, \mathbf{4}) ; \mathrm{Fe}(\mathbf{2})$. 
Received \{\{to be completed by the Editorial Office\}\}

[1] P. Gouzerh, A. Proust, Chem. Rev., 1998, 98, 77-112.

Main-Goup Element, Organic, and Organometallic Derivatives of Polyoxometalates

[2] C. Sanchez, G. J. de Soler-Illia, F. Ribot, T. Lalot, C. R. Mayer, V. Cabuil, Chem. Mater., 2001, 13, 3061-3083.

Designed Hybrid Organic-Inorganic Nanocomposites from Functional Nanobuilding Blocks

[3] C. Hu, Y. Wang, Y. Li, E. Wang, Chem. J. Internet, 2001, 3, No pp. given.

[4] C. R. Mayer, R. Thouvenot, T. Lalot, Chem. Mater., 2000, 12, 257-260.

New Hybrid Covalent Networks Based on Polyoxometalates: Part 1. Hybrid Networks

Based on Poly(ethyl methacrylate) Chains Covalently Cross-linked by Heteropolyanions:

Synthesis and Swelling Properties

15 [5] C. R. Mayer, R. Thouvenot, T. Lalot, Macromolecules, 2000, 33, 4433-4437.

Hybrid Hydrogels Obtained by the Copolymerization of Acrylamide with Aggregates of

Methacryloyl Derivatives of Polyoxotungstates. A Comparison with Polyacrylamide

Hydrogels with Trapped Aggregates

[6] A. R. Moore, H. Kwen, A. M. Beatty, E. A. Maatta, Chem. Commun., 2000, 1793-1794.

Organoimido-polyoxometalates as polymer pendants

[7] C. G. Hamaker, A. M. Beatty, E. A. Maatta In Abstr. Pap. - Am. Chem. Soc.; 2001; pp INOR-341.

[8] H. Zeng, G. R. Newkome, C. L. Hill, Angew. Chem. Int. Ed., 2000, 39, 1772-1774. Poly(polyoxometalate) dendrimers: molecular prototypes of new catalytic materials R. C. Schroden,

Direct Synthesis of Ordered Macroporous Silica Materials Functionalized with Polyoxometalate Clusters

[10] J. L. Stark, V. G. Young, Jr., E. A. Maatta, Angew. Chem., Int. Ed. Engl., 1995, 34, 25472548.

A functionalized polyoxometalate bearing a ferrocenylimido ligand: preparation and structure of $[(\mathrm{FcN}) \mathrm{Mo6} \mathrm{O} 18] 2$

[11] M. T. Pope, Heteropoly and Isopoly Oxometalates; Springer Verlag: Berlin, 1983.

[12] R. Villanneau, A. Proust, F. Robert, P. Gouzerh, J. Chem. Soc., Dalton Trans., 1999, 421426.

Coordination chemistry of lacunary Lindqvist-type polyoxometalates: cubic vs. squareantiprismatic coordination

[13] M. Sadakane, M. H. Dickman, M. T. Pope, Angew. Chem. Int. Ed., 2000, 39, 2914-2916. Controlled assembly of polyoxometalate chains from lacunary building blocks and

[14] Q.-H. Luo, R. C. Howell, M. Dankova, J. Bartis, C. W. Williams, W. D. Horrocks, Jr., V. G. Young, A. L. Rheingold, L. C. Francesconi, M. R. Antonio, Inorg. Chem., 2001, 40, 18941901.

Coordination of Rare-Earth Elements in Complexes with Monovacant Wells-Dawson Polyoxoanions

[15] L. Ruhlmann, J. Canny, R. Contant, R. Thouvenot, Inorg. Chem., 2002, 41, 3811-3819. 
Di- and Tricobalt Dawson Sandwich Complexes: Synthesis, Spectroscopic Characterization, and Electrochemical Behavior of $\mathrm{Na} 18[(\mathrm{NaOH} 2) 2 \mathrm{Co} 2(\mathrm{P} 2 \mathrm{~W} 15 \mathrm{O} 56) 2]$ and

$\mathrm{Na} 17[(\mathrm{NaOH} 2) \mathrm{Co} 3(\mathrm{H} 2 \mathrm{O})(\mathrm{P} 2 \mathrm{~W} 15 \mathrm{O} 56) 2]$

[16] T. M. Anderson, X. Zhang, K. I. Hardcastle, C. L. Hill, Inorg. Chem., 2002, 41, 2477-2488. Reactions of Trivacant Wells-Dawson Heteropolytungstates. Ionic Strength and Jahn-Teller Effects on Formation in Multi-Iron Complexes

[17] L. Xu, H. Zhang, E. Wang, D. G. Kurth, Z. Li, J. Mat. Chem., 2002, 12, 654-657. Photoluminescent multilayer films based on polyoxometalates

[18] R. Neumann, Prog. Inorg. Chem., 1998, 47, 317-370. Polyoxometalate complexes in organic oxidation chemistry

[19] A. Müller, S. Sarkar, S. Q. N. Shah, H. Bogge, M. Schmidtmann, S. Sarkar, P. Kogerler, B. Hauptfleisch, A. X. Trautwein, V. Schunemann, Angew. Chem. Int. Ed., 1999, 38, 32383241.

Archimedean Synthesis and Magic Numbers: "Sizing" Giant Molybdenum-Oxide-Based Molecular Spheres of the Keplerate Type

[20] M. Piepenbrink, M. U. Triller, N. H. J. Gorman, B. Krebs, Angew. Chem. Int. Ed., 2002, 41, 2523-2525.

Bridging the Gap between Polyoxometalates and Classic Coordination Compounds: A Novel Type of Hexavanadate Complex

[21] B. Hasenknopf, R. Delmont, P. Herson, P. Gouzerh, Eur. J. Inorg. Chem., 2002, 1081-1087. Anderson-type heteropolymolybdates containing tris(alkoxo) ligands: Synthesis and structural characterization

[22] M. I. Khan, Q. Chen, J. Zubieta, D. P. Goshorn, Inorg. Chem., 1992, 31, 1556-1558. Hexavanadium polyoxoalkoxide anion clusters: structures of the mixed-valence species $(\mathrm{Me} 3 \mathrm{NH})[\mathrm{VIV} 5 \mathrm{VVO} 7(\mathrm{OH}) 3\{\mathrm{CH} 3 \mathrm{C}(\mathrm{CH} 2 \mathrm{O}) 3\} 3]$ and of the reduced complex $\mathrm{Na} 2[\mathrm{VIV} 6 \mathrm{O} 7\{\mathrm{CH} 3 \mathrm{CH} 2 \mathrm{C}(\mathrm{CH} 2 \mathrm{O}) 3\} 4]$

[23] Q. Chen, D. P. Goshorn, C. P. Scholes, X. L. Tan, J. Zubieta, J. Am. Chem. Soc., 1992, 114, 4667-4681.

Coordination compounds of polyoxovanadates with a hexametalate core. Chemical and structural characterization of [VV6O13[(OCH2)3CR]2]2-, [VV6O11(OH)2[(OCH2)3CR]2], [VIV4VV2O9(OH)4[(OCH2)3CR]2]2-, and [VIV6O7(OH)6] $(\mathrm{OCH}) 3 \mathrm{CR}] 2] 2$

[24] A. Mueller, J. Meyer, H. Boegge, A. Stammler, A. Botar, Z. Anorg. Allg. Chem., 1995, 621, $1818-1831$.

Cis-/trans-Isomerization of bis(trisalkoxy)hexavanadates: cis-

$\mathrm{Na} 2[\mathrm{VIV} 6 \mathrm{O} 7(\mathrm{OH}) 6\{(\mathrm{OCH} 2) 3 \mathrm{CCH} 2 \mathrm{OH}\} 2] . c n t d o t .8 \mathrm{H} 2 \mathrm{O}$, cis-

(CN3H6)3[VIVVV5O13 $\{(\mathrm{OCH} 2) 3 \mathrm{CCH} 2 \mathrm{OH}\} 2]$.cntdot.4.5H2O and trans-

(CN3H6)2[VV6O13\{(OCH2)3CCH2OH $\} 2] . c n t d o t . H 2 O$

[25] Y. Hou, C. L. Hill, J. Am. Chem. Soc., 1993, 115, 11823-11830.

Hydrolytically stable organic triester capped polyoxometalates with catalytic oxygenation activity of formula [RC(CH2O)3V3P2W15O59]6- $(\mathrm{R}=\mathrm{CH} 3, \mathrm{NO} 2, \mathrm{CH} 2 \mathrm{OH})$

[26] M. I. Khan, Q. Chen, D. P. Goshorn, H. Hope, S. Parkin, J. Zubieta, J. Am. Chem. Soc., 1992, 114, 3341-3346.

Polyoxo alkoxides of vanadium: the structures of the decanuclear vanadium(IV) clusters [V10O16 $\{\mathrm{CH} 3 \mathrm{CH} 2 \mathrm{C}(\mathrm{CH} 2 \mathrm{O}) 3\} 4] 4-$ and [V10O13 $\{\mathrm{CH} 3 \mathrm{CH} 2 \mathrm{C}(\mathrm{CH} 2 \mathrm{O}) 3\} 5]$

[27] R. Delmont, A. Proust, F. Robert, P. Herson, P. Gouzerh, C. R. Acad. Sci. Paris, Série IIc, 2000, 3, 147-155.

The building block approach to the synthesis of polyoxotrisalkoxometalates

[28] M. T. Pope Comprehensive Coordination Chemistry; 1 ed.; S. G. Wilkinson, R. D. Gillard and J. A. McCleverty, Eds.Pergamon Press: Oxford, 1987; Vol. 3; pp 1023-1056. Isopolyanions and Heteropolyanions

[29] P. A. Lorenzo-Luis, P. Gili, Recent Res. Devel. Inorganic Chem., 2000, 2, 185-196. 
Polyoxometalates with an Anderson-Evans structure

[30] K. Nomiya, T. Takahashi, T. Shirai, M. Miwa, Polyhedron, 1987, 6, 213-218. Anderson-Type Heteropolyanions of Molybdenum(VI) and Tungsten(VI)

[31] L. Bi, E. Wang, L. Xu, R. Huang, Inorg. Chim. Acta, 2000, 305, 163-171. Synthesis, properties and crystal structure of some polyoxometallates containing the tris(hydroxymethyl)-aminomethane cation

[32] Q. Chen, J. Zubieta, Inorg. Chim. Acta, 1992, 198-200, 95-110. Structural investigations of the hexavanadium core $\{\mathrm{V} 6 \mathrm{O} 19\}$ in 'oxidized', mixed valence and 'reduced' clusters of the type [VV6-nVIVnO13-n $(\mathrm{OH}) \mathrm{n}\{(\mathrm{OCH} 2) 3 \mathrm{CR}\} 2] 2-, \mathrm{n}=0,3$ and 6

[33] I. L. Botto, A. C. Garcia, H. J. Thomas, J. Phys. Chem. Solids, 1992, 53, 1075-1080. Spectroscopical Approach to Some Heteropolymolybdates with the Anderson Structure

[34] Pearson, J. Am. Chem. Soc., 1963, 85, 3533-3539. HSAB

[35] J. F. W. Keana, M. D. Ogan, Y. Lu, M. Beer, J. Varkey, J. Am. Chem. Soc., 1986, 108, 7957-7963.

Functionalized Keggin- and Dawson-type cyclopentadienyltitanium heteropolytungstate anions: small, individually distinguishable labels for conventional transmission electron microscopy. 2. Reactions

[36] N. Hur, W. G. Klemperer, R.-C. Wang Inorg. Synth.; A. P. Ginsberg, Ed.John Wiley \& Sons: New York, 1990; Vol. 27.

Tetrabutylammonium octamolybdate(VI)

[37] CRYSTALS, An Advanced Crystallographic Computer Program; D. J. Watkin, J. R. Carruthers, P. W. Betteridge, Eds.; Chemical Crystallography Laboratory: Oxford, 1989

[39] Shelxs 86, Program for Crystal Structure Solution; G. M. Sheldrick, Ed.; University of Göttingen: Göttingen, 1986

[40] N. Walker, D. Stuart, Acta Cryst., 1983, A39, 158-166. DIFABS 